\title{
ASZTALI 3D NYOMTATÓ FEJLESZTÉSE
}

\author{
Derekas Csaba \\ MSc hallgató, Miskolci Egyetem, Szerszámgépészeti és Mechatronikai Intézet, Szerszámgépek Intézeti Tanszék \\ 3515 Miskolc, Miskolc-Egyetemváros, e-mail: abrcsabi@gmail.com
}

\author{
Kiss Dániel \\ egyetemi tanársegéd, Miskolci Egyetem, Szerszámgépészeti és Mechatronikai Intézet, \\ Szerszámgépek Intézeti Tanszék \\ 3515 Miskolc, Miskolc-Egyetemváros, e-mail: kiss.daniel@uni-miskolc.hu
}

\begin{abstract}
Absztrakt
Ebben a cikkben bemutatjuk egy, az FDM (Fused Deposition Modeling) technológián alapuló gyors prototipus gép tervezését és kivitelezését, valamint az ezzel készült próbadarabok nyomtatásának eredményeit. A gép tervezési alapját egy meglévö ISEL 5D marógép biztositotta, amelyböl eltávolitottuk az orientációs mozgásokat megvalósitó két tengelyt, majd egy Arduino Uno mikrovezérlövel megvalósitottuk a lineáris mozgásokat biztositó három tengely mozgásvezérlését. Az elkészült 3D nyomtatóval különbözö alapanyagokból és nyomtatási paraméterekkel próbadarabokat nyomtattunk ki a tesztelés során, amelyek eredményeiröl ismertetjük.
\end{abstract}

Kulcsszavak: 3D nyomtató, FDM, mikrovezérlö

\begin{abstract}
In this paper, we present the design and construction of a rapid prototyping machine based on FDM (Fused Deposition Modeling) technology and the results of the test pieces made with it. The design basis of the machine was provided by an existing ISEL 5D milling machine, from which the two axes realizing the orientation movements were removed, and then the motion control of the three axes realizing the linear movements was realized with an Arduino Uno microcontroller. With the completed $3 D$ printer, we printed test pieces from different raw materials and printing parameters during the testing, the results of which are reported.
\end{abstract}

Keywords: $3 D$ printer, FDM, microcontroller

\section{Bevezetés}

A 3D nyomtatás ötlete már az 1970-es években felmerült, de az első kísérletek 1981-ből származnak. Dr. Hideo Kodama elsőként írta le a rétegenkénti gyártást, létrehozva az SLA (StereoLithogrAphy) elődjét, ahol a fényérzékeny gyantát ultraibolya fényben polimerizálták.1984-ben Alain Le Méhauté, Olivier de Witte és Jean-Claude André érdeklődését felkeltette a sztereolitográfia alkalmazása, de az üzleti perspektíva hiánya miatt azt elvetették. Charles Hull is érdeklődött a technológia iránt, és 1986ban benyújtotta az első szabadalmat a sztereolitográfiához. Megalapította a 3D Systems Corporation-t, majd 1988-ban kiadta az SLA-1-et, az első kereskedelmi terméküket. 1988-ban Carl Deckard, a Texasi Egyetemen szabadalmat nyújtott be az SLS (Selective Laser Sintering) technológiára, egy másik $3 D$ nyomtatási technikára, amelyben a porszemeket lézerrel helyileg összeolvasztják. Időközben Scott Crump, a Stratasys Inc. társalapítója szabadalmat nyújtott be az FDM-re (Fused Deposition Modeling) 
[1]. Az elmúlt évek nagyon fontosak voltak a $3 D$ nyomtatás szempontjából. Az FDM szabadalmi lejártával az évtized első évei a $3 D$ nyomtatás évei lettek. Az adalékanyagok gyártása ekkor vált valódi és megfizethető prototípus- és gyártástechnikává a vállalkozások számára, új lehetőségeket nyitva meg. Ezen okok miatt a hobbi célokra használható $3 D$ nyomtatási folyamatok széles körben elérhetővé váltak, így ezek az eszközök egyszerü és költséghatékony alkatrészekből építhetők fel. A Miskolci Egyetem Szerszámgépek Intézeti Tanszéke a tervezési módszertani irányelvek felhasználásával javaslatot tett több eszköz tervezésére [2]. Ide tartoznak a hegesztett földmunkagépkarok mérőállomáskoncepciói [3], az ipari mérögépek [4], a mechatronikai rendszerek tervezése [5], a gördülőcsapágyak kopásának és a maradandó élettartamának meghatározásához alkalmas vizsgálóberendezés [6], valamint marógépek forgácskihordójának tervezése [7]. A fenti tapasztalatok és a tervezésmódszertani elvek felhasználásával egy $3 D$-s nyomtatót építettünk az FDM nyomtatási technológiával. A gép mérete miatt annak munkatere kisméretü alkatrészek nyomtatását valósíthatja meg.

\section{A fejlesztés lépései}

Ebben a részben a fejlesztési folyamat lépéseit ismertetjük. Az új asztali $3 D$ nyomtató alapja egy $I S E L$ $5 D$ marógép volt, mely szerkezetének elemzését a következő alfejezet tárgyalja.

\subsection{A gép szerkezetének elemzése}

Az $5 D$ marógép három lineáris tengellyel $(X, Y, Z)$ és két forgástengellyel $(A, C)$ rendelkezik. Mindegyik lineáris tengelyt egy léptetőmotor és egy golyósorsó-anya mechanizmus hajtja, míg a forgótengelyeken egy-egy léptetőmotor hajt, vezérmüszíjjal. A tengelyek mozgástartományát végálláskapcsolók, a hajtásokat pedig az ISEL öttengelyes vezérlője vezérli (1. ábra).

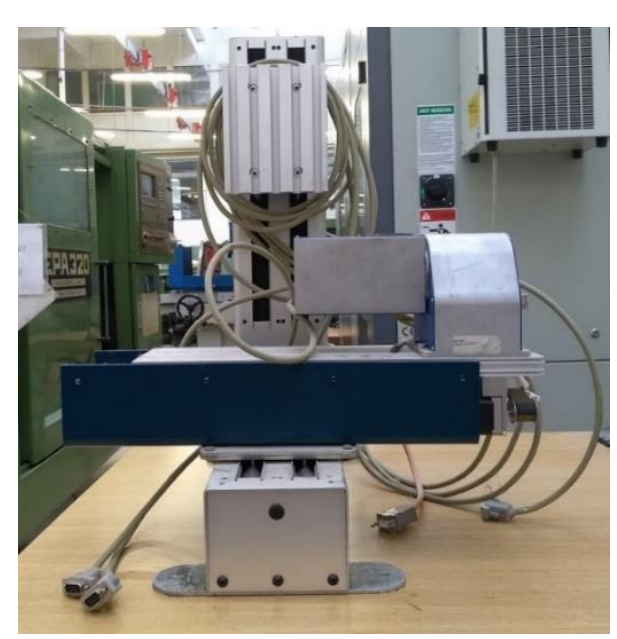

a) Az eredeti 5D-s marógép

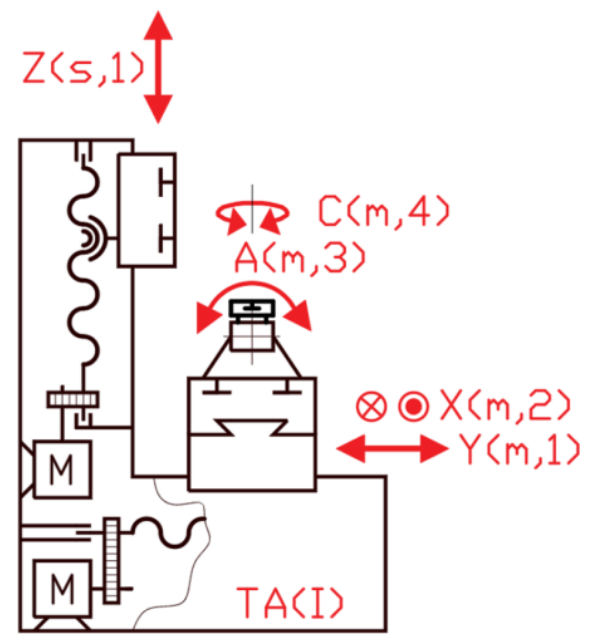

b) Gép struktúra

\section{1. ábra. Az eredeti gép és struktúrája}

A gép szerkezetének azonosítása:

- TA (I) bázis,

- Z (s, 1) Z tengely, a szerszám lineáris mozgása, 1. prioritás,

- Y $(\mathrm{m}, 1) \mathrm{Y}$ tengely, az alkatrész lineáris mozgása, 1. prioritás, 
- $X(m, 2) X$ tengely, az alkatrész lineáris mozgása, 2. prioritás,

- A (m, 3) A tengely, az X tengely körüli forgatás az alkatrésznél, 3. prioritás,

- $\quad \mathrm{C}(\mathrm{m}, 4) \mathrm{C}$ tengely, forgatás az alkatrész Z / Y tengelye körül, 4. prioritás.

Értékelemző módszert alkalmaztunk a $3 D$ asztali nyomtatógép új funkcióinak megtalálásához. A fő szempont az ár, a vezérlés bonyolultsága és a fejlesztési folyamat ideje volt. Az értékelemzés eredményeként bebizonyosodott, hogy a legjobb új megoldások a háromtengelyes $3 D$ nyomtató és a háromtengelyes $C N C$ marógép lenne (1. táblázat). Az öttengelyes $C N C$ marógépet, a háromtengelyes lézervágó gravírozógépet és az öttengelyes 3D nyomtatót túl nehéz lett volna megvalósítani.

1. táblázat. Értékelemző módszer eredménye

\begin{tabular}{|c|c|c|c|c|}
\hline & \multicolumn{3}{|c|}{ értékelési szempontok } & \multirow{2}{*}{$\Sigma$} \\
\hline & ár & összetettség & ráfordított munka & \\
\hline szempont súlya & 40 & 30 & 20 & \\
\hline öttengelyes marógép pontszáma & 4 & 3 & 7 & \\
\hline pontszám*súly & 160 & 90 & 140 & 390 \\
\hline háromtengelyes marógép pontszáma & 6 & 8 & 8 & \\
\hline pontszám*súly & 240 & 240 & 160 & 640 \\
\hline lézervágó- gravírozógép pontszáma & 3 & 6 & 5 & \\
\hline pontszám*súly & 120 & 180 & 100 & 400 \\
\hline háromtengelyes alakra hegesztő-gép pontszáma & 6 & 8 & 6 & \\
\hline pontszám*súly & 240 & 240 & 120 & 600 \\
\hline öttengelyes alakra hegesztő-gép pontszáma & 3 & 3 & 4 & \\
\hline pontszám*súly & 120 & 90 & 80 & 290 \\
\hline revolverfejes többfunkciós gép pontszáma & 2 & 2 & 3 & \\
\hline pontszám*súly & 80 & 60 & 60 & 200 \\
\hline
\end{tabular}

\subsection{Az eszköz számítógépes tervezése}

Az értékelemzés után a következő mérföldkő a $3 D$ asztali nyomtató számítógéppel segített tervezése volt. Az alkatrészek $3 D$ geometriai modellezését és a termék összeszerelésének modellezését a Siemens NX PLM 11 szoftverrel végeztük. Mérnöki elemzéseket hajtottunk végre, például kinematikai szimulációkat, ütközés detektálást a különböző tengelyek mozgatása során. A 2. ábra a tervezett $3 D$ asztali nyomtató összeszerelési modelljét mutatja.

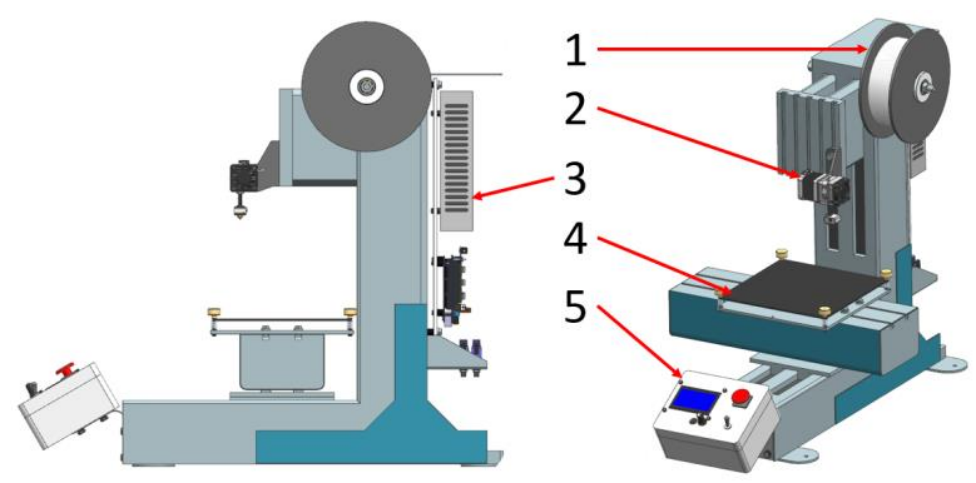

2. ábra. A 3D nyomtató végső modellje 
Az új berendezés végleges kialakítása (2. ábra):

1. száladagoló,

2. extruder,

3.tápegység,

4. füthető ágy,

5. vezérlö.

Ezek az új alkatrészek kereskedelmi és szabványosított termékek. A megvásárolt cikkek költségszámítását a 2. táblázat tartalmazza.

2. táblázat. Költségkalkuláció eredménye

\begin{tabular}{|c|c|c|c|}
\hline sorszám & megnevezés & mennyiség & darabár [Ft] \\
\hline 1 & MK8 komplett extrúder $1,75+0,4$ & 1 & 12700 \\
\hline 2 & MK3 ALU-fütött asztal & 1 & 5080 \\
\hline 3 & ABS-Filament natúr 1,75 & 1 & 6700 \\
\hline 4 & thermistor & 2 & 65 \\
\hline 5 & Jumper, piros, $\mathrm{RM}=2,54 \mathrm{~mm}$ & 30 & 5,08 \\
\hline 6 & Krimp. érintkező & 200 & 4,74 \\
\hline 7 & Csatlakozó ház 1p NSR-01 & 50 & 8,62 \\
\hline 8 & Csatlakozó ház 2p NSR-02 & 50 & 10,19 \\
\hline 9 & Csatlakozó ház 3p NSR-03 & 50 & 4,5 \\
\hline 10 & Csatlakozó ház 4p NSR-04 & 20 & 6,45 \\
\hline 11 & D-SUB aljzat, lengő, 9pól. (mama) & 5 & 36 \\
\hline 12 & Zsugorcső, kék 4/2mm BL & 3 & 28 \\
\hline 13 & Zsugorcső, kék 6/3mm BL & 3 & 38,1 \\
\hline 14 & Zsugorcső, kék 10/5mm BL & 3 & 91,44 \\
\hline 15 & RepRap grafikus Smart Controller 12864 & 1 & 5842 \\
\hline 16 & $\begin{array}{l}\text { Arduino Mega+Ramps 1.4+ A4988 } \\
\text { csomag }\end{array}$ & 1 & 10795 \\
\hline 17 & Tápegység 360W 12V 30A S-360-12 & 1 & 8200 \\
\hline & & \multicolumn{2}{|c|}{$\Sigma 52494,52$ HUF } \\
\hline
\end{tabular}

\section{Az összeszerelt nyomtató tesztelése}

Az újonnan összeállított alkatrészek alkotják a $3 D$ asztali nyomtatót. Az Arduino Uno mikrokontrolleren alapul a hardver vezérlö, amely nyílt forráskódú szoftverfejlesztö platformmal rendelkezik. Ramps 1.4 egységgel van összekötve, amely a léptető motorokat vezérli az A4988 léptető motor vezérlőkön keresztül.

A gépet függetlenül a számítógéptől a 12864 típusú grafikus intelligens vezérlővel is lehet üzemeltetni. Az adatokat egy secure digital (SD) kártya segítségével lehet feltölteni a gépre. A hardverrel való kommunikációhoz a Marlin 1.1 nyílt forráskódú szoftvert alkalmaztuk. A meghajtók tesztelése és finomhangolása után a háromtengelyes $3 D$ asztali nyomtató készen állt a különböző mintadarabok nyomtatásához. A géphez a kódot a Cura 4.0 szoftver generálja a $3 D$ STL modell alapján. A teszt során $A B S$ (akrilnitril-butadién-sztirol) és PLA (politejsav) szálakat is alkalmaztunk. A gép felépítése nem optimális az $A B S$-sel történő nyomtatáshoz, mivel az anyag érzékeny a kis légáramokra is. Néhány $A B S$ alkatrész megrepedt a nyomtatási folyamat során. A vizsgálati eredmények sokkal jobbak voltak a PLA alapanyaggal. A $3 D$ nyomtatás után az alkatrészek szilárdsága nagyobb volt, a felület simább és a rétegek kötése erősebb volt. 


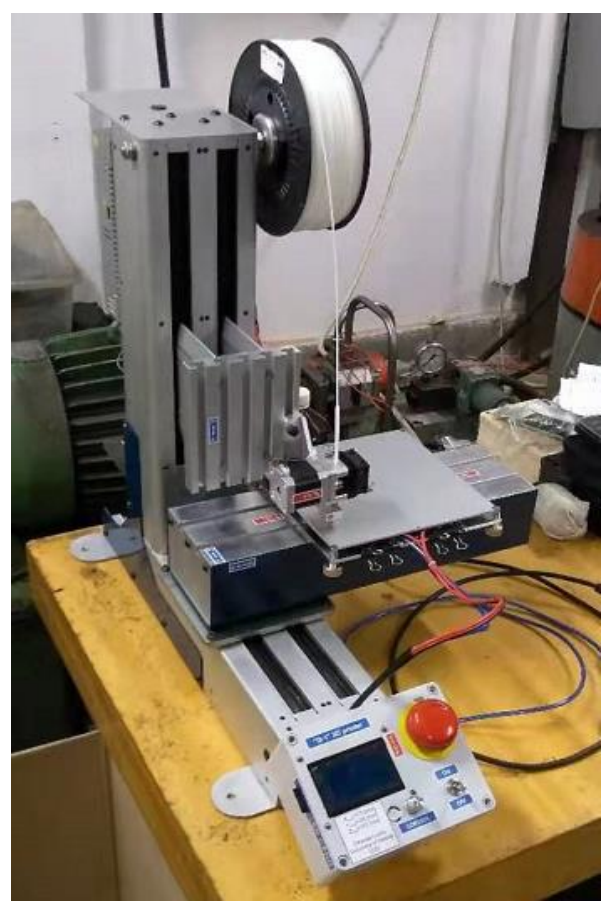

3. ábra. Az összeszerelt 3D nyomtató

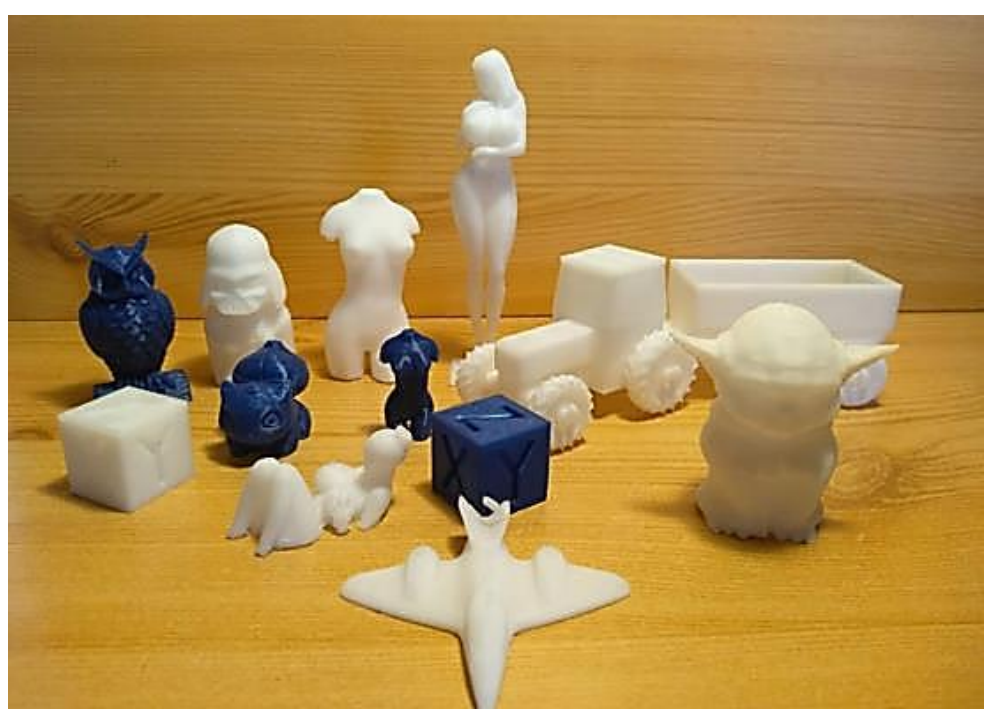

\section{4. ábra. Különböző alapanyagból nyomtató próbadarabok}

Néhány $A B S$ anyagból nyomtatott apró alkatrész megfelelő termékeket eredményezett (4. ábra). Amikor azonban a nyomtatott alkatrészek méretei elérték a kritikus mérethatárt, a nyomtatási folyamat után repedezni kezdtek. A PLA-szálból nyomtatott alkatrészek jobb termékeket eredményeztek, az egyik anyagtulajdonságának köszönhetően, amely kevésbé érzékeny a nyomtatás közbeni légáramra (a repedés hajlam nem jelent meg a nyomtatás után). Az 5. ábra egy $3 D$ nyomtatott részt mutat, PLAszállal. 


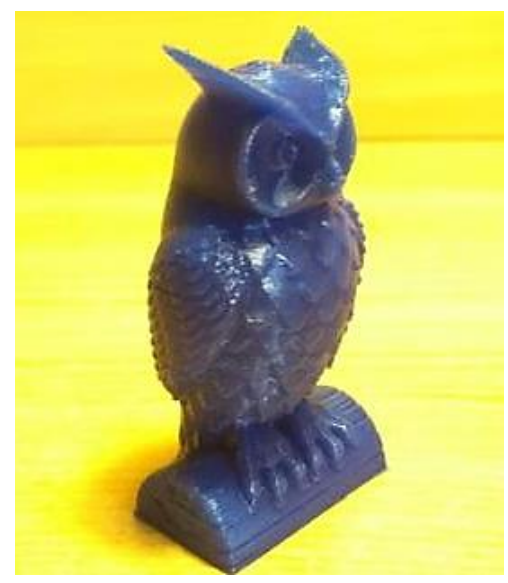

5. ábra. PLA alapanyagból nyomtatott próbadarab

\section{4. Összegzés}

Az elmúlt években az $F D M$ technológiát alkalmazó $3 D$ nyomtatók nagyon elterjedtek egyszerủ felépítésük miatt. Ezek az eszközök már megjelentek a mindennapi használatban is. Ebben a cikkben megvizsgáltuk egy rendelkezésre álló ISEL $5 D$ marógép átalakításának lehetőségét arra, hogy alkalmas legyen $3 D$ asztali nyomtató építésére. A folyamat előtt értékelemzést végeztünk, amely megerősítette, hogy a rendelkezésre álló eszközök biztosítják az optimális kiindulópontot a nyomtató felépítéséhez. A nyomtató $3 D$ tervezését és elemzését követte a hiányzó alkatrészek beszerzése és összeszerelése, majd a nyomtatási paraméterek és azok hatásainak vizsgálata, valamint a $3 D$ asztali nyomtató tesztelése. Megállapítható, hogy a jelenlegi eredmények megerősítették a tervezés előtti feltételezést, miszerint az elkészített nyomtató jól használható olyan esetekben, ahol az FDM technológia pontossága elegendő.

\section{Köszönetnyilvánítás}

A cikkben ismertetett kutató munka az EFOP-3.6.1-16-2016-00011 jelü „Fiatalodó és Megújuló Egyetem - Innovatív Tudásváros - a Miskolci Egyetem intelligens szakosodást szolgáló intézményi fejlesztése" projekt részeként - a Széchenyi 2020 keretében - az Európai Unió támogatásával, az Európai Szociális Alap társfinanszírozásával valósul meg.

\section{Irodalom}

[1] The Ultimate Guide to Stereolithography (SLA) 3D printing - white paper, Marc 2017, formlabs.com

[2] Takács, Gy.; Zsiga, Z.; Makó, I.; Hegedüs, Gy.: Gyártóeszközök módszeres tervezése, Budapest, Hungary: Nemzeti Tankönyvkiadó (2011), 187 p.

[3] Jakab, E.; Takács, Gy.; Hegedűs, Gy.: Méröállomás koncepciók hegesztett földmunkagépkarokhoz, GÉP 53: 6-7 pp. 45-48., 4 p. (2002), ISSN 0016-8572

[4] Hegedủs, Gy.: A módszeres géptervezés alkalmazása ipari mérögép fejlesztése estén, PhD Students Conference 2002, Section publication of the Faculty of Mechanical Engineering, Miskolc, Hungary: University of Miskolc Innovation and Technology Transfer Center, (2003) pp. 98-103., 6 p. 
[5] Takács, Gy.; Patkó, Gy.; Csáki, T.; Szilágyi, A.; Hegedűs, Gy.: Development of Mechatronic Systems at the Institute for Mechatronics at the University of Miskolc, 2006 IEEE International Conference on Mechatronics, pp. 326-331. https://doi.org/10.1109/ICMECH.2006.252548

[6] Hegedűs, Gy.; Barak, A.; Barna, B.; Demeter, P.; Simon, G.; Szilágyi, A.; Takács, Gy.: Development of analyzing equipment of the remanent lifetime on roller bearings, MicroCAD 2010: XXIV. microCad International Scientific Conference: Section L: Machine and structure design, Miskolc, Hungary: University of Miskolc, (2010) pp. 47-52.

[7] Szabó, K.; Takács, Gy.; Hegedűs, Gy.; Tóth, S. G.: Examination of Design Methodology of Screw Conveyors, Design of Machines and Structures 9: 1 pp. 58-63., (2019) 